\title{
A REAL-TIME UPDATED PORTRAYAL OF COVID-19 DIAGNOSIS AND THERAPEUTIC OPTIONS
}

\author{
Nazim Hussain ${ }^{1}$, Aqeel Ahmed ${ }^{1}$, Muhammad Imran Khan ${ }^{2}$ (D), Wenhua Zhu ${ }^{3}$, \\ Zahid Nadeem ${ }^{4}$, Muhammad Bilal ${ }^{5 *}$ (iD
}

${ }^{1}$ Centre for Applied Molecular Biology (CAMB), University of the Punjab, Lahore 53700, Pakistan.

${ }^{2}$ Hefei National Lab for Physical Sciences at the Microscale and the Centers for Biomedical Engineering, University of Science and Technology of China, Hefei 230026, Anhui, P. R. China.

${ }^{3}$ Department of Biochemistry and Molecular Biology, School of Basic Medical Sciences, Xi'an JiaoTong University Health Science Center, Xi'an, Shaanxi, China.

${ }^{4}$ Department of Imaging and Nuclear Medicine, School of Basic Medical Sciences, Xian JiaoTong University, health science center, No. 76 Yanta West Road, Xian, Shaanxi 710061, China

${ }^{5}$ School of Life Science and Food Engineering, Huaiyin Institute of Technology, Huaian 223003, China.

Received - August 27, 2020; Revision - September 14, 2020; Accepted - September 27, 2020

Available Online - October 08, 2020

DOI: http://dx.doi.org/10.18006/2020.8(Spl-1-SARS-CoV-2).S21.S33

KEYWORDS
COVID-19
Diagnosis
Immune response
Pathogenesis
Prevention
Treatment

\begin{abstract}
The outbreak of COVID-19 seems to be the worst pandemic of history. The pandemic sprouting from China has created an uncertain situation globally. The rapid prevalence of this infectious agent has severely paralyzed every discipline of life at the domestic and international global levels within a few months after onset. The exponential growth of COVID-19 infected admissions in hospitals has oversaturated hospitals capacity, especially in developing and third world countries. Despite efforts of global communities and organizations, several developed countries are especially more affected due to a good economy and more intercontinental traveling. Due to extensive geographical spread, rapid transmission inclination, and severity of disease caused by COVID-19, the World Health Organization (WHO) declared "Public Health Emergency of International Concern". The ripple influence of this pandemic has brought potential challenges to worldwide health-care systems. It might trigger a "far-reaching" global economic crisis if the virus spread is not strictly curbed. Therefore, the scientific concern has heightened on this novel Corona virus. This review intends to show a complete, updated, and streamlined picture of the COVID-19 pandemic. The first half of this review discusses the basic molecular virology of COVID-19, pathogenesis, immune response, and its transmission. The second part light on clinical features, diagnostic techniques, and facilities in Pakistan. Finally, along with the prevention and possible treatment of COVID-19, the opportunities and future perspectives are also discussed. In particular, the aim of this review is the true portrayal of RT-PCR testing in Pakistan.
\end{abstract}

* Corresponding author

E-mail: nazim.camb@pu.edu.pk (N. Hussain); bilaluaf@hotmail.com (M. Bilal).

Peer review under responsibility of Journal of Experimental Biology and Agricultural Sciences.

Production and Hosting by Horizon Publisher India [HPI] (http://www.horizonpublisherindia.in/).

All rights reserved.
All the articles published by Journal of Experimental Biology and Agricultural Sciences are licensed under a Creative Commons Attribution-NonCommercial 4.0 International License Based on a work at www.jebas.org.

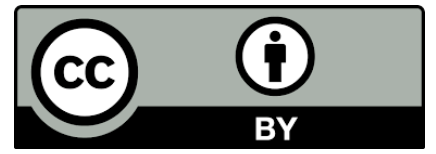




\section{Introduction}

COVID-19 is the major health concern of the $21^{\text {st }}$ century affecting all the countries of the world. The duration between the onset of the outbreak and the declaration of pandemic ranges just three months (Keam et al., 2020; Ciotti et al., 2020). By the end of August, WHO reported that 38000 deaths and 1.8 million cases were reported during the last week of August. At the same time, WHO mentioned that after the addition of these new cases total global figure of deaths reached 800000, while making 25 million confirmed cases have been reported since December 2019 (WHO, 2020). COVID-19 is the term referred to the current pandemic of novel SARS-2 (corona virus)-mediated respiratory infection, which erupted in late 2019 in Wuhan, China. Corona viruses are positive-sense, enveloped RNA (as genetic material) virus with diameter 60- $140 \mathrm{~nm}$, outer surfacing like a crown when viewed through an electron microscope, hence got the name "corona" due to crown-like appearance (Richman et al., 2016).

Two major respiratory problems similar to the current pandemic occurred in the first quarter of the $21^{\text {st }}$ century, where animal origin beta-viruses crossover to human beings resulted in major respiratory infections. First, highly infectious corona viruses emerged in 2002, when a novel beta-type SARS virus having bat origin (intermediate host-palm civet cats) caused severe respiratory syndrome that affected more than 8000 peoples with over 900 deaths (Chan-Yeung \& Xu, 2003). The second major health event was caused by bat origin MERS (Middle East Respiratory Syndrome virus) corona virus in Saudi Arabia (intermediate hostcamel) that cause serious respiratory problems in approximately 2500 individuals and taken the lives of 858 individuals (Memish et al., 2020).

The first confirmed COVID-19 case was reported in Wuhan, city of China, in December 2019 (Bilal et al., 2020; Dong et al., 2020; Yang et al., 2020). In the following days, infection not only spread in China but also in other countries in the world. On Jan 30, 2020, the WHO declared this disaster as a Public Health Emergency of International Concern. Therefore, health institutions called for a collective response at national and international levels to create the desired and systemized health system to stop this unstoppable(Holshue et al., 2020; Phan et al., 2020). On 26 February 2020, the first confirmed COVID-19 case (a student returned from Iran) was reported in the Sindh province of Pakistan. By the $10^{\text {th }}$ of April, had 4695 cases; among them, $15.5 \%$ of patients had already recovered, $1 \%$ were critical, while $1.4 \%$ were under critical care (Abid et al., 2020). According to the WHO update, by the end of August, the figure of confirmed cases in Pakistan reached 288717, with 498 deaths (WHO, 2020).

In the earlier days, when we looked at the prevalence in Pakistan via national and international statistics of COVID-19 patients, we found that the number of patients were going to goes on increasing exponentially. According to the fresh WHO reports, Pakistan is recovering as compared with previous statistics. For instance, during the last week of August, a 20\% reduction in new cases and a $24 \%$ reduction in death has been observed (WHO, 2020). Government and research institutes are trying to play their role in screening the majority of the population, but due to limited resources, only a small fraction of the population is screened daily. New initiatives are being taken to establish more diagnostic centers, and working institutions are trying to enhance their capacity to increase screening capacity daily. This review is done to show a complete, updated, and streamlined picture on the COVID-19 pandemic, especially in Pakistan. The first part of this review will discuss basic molecular virology of COVID-19, pathogenesis, immune response, and its transmission. The second part will shed light on clinical features, diagnostic techniques, and facilities in Pakistan and finally, the prevention and possible treatment of this novel SARS-CoV-2. The aim of this review is the true portrayal of RT-PCR testing in Pakistan.

\section{Virology of COVID-19}

Corona virus has a big family of viruses that cause infections of variable intensity ranging from commonly ignored common cold to acute, severe, scary, and painful respiratory syndromes (Keni et al., 2020). COVID-19 is the term referred to as the current pandemic of novel SARS-2 (corona virus) mediated respiratory infection, which erupted in late 2019 in Wuhan, China (Yang et al., 2020). Corona viruses are positive-sense, enveloped RNA (as genetic material) virus with diameter $60-140 \mathrm{~nm}$, outer surfacing like a crown when viewed through an electron microscope, hence got the name "corona" due to crown-like appearance (Richman et al., 2016). Some are known to cause significant respiratory issues (like SARS-CoV, MARS, etc.). In contrast, few other corona viruses are present in human circulation, known to cause low to mild respiratory infection, namely OC-43, NL-63, HKU-1, and 229-E.

The COVID-19 is a single-stranded positive-sense 30kb RNA that encodes 9860 a.a (Chan et al., 2020; Chen et al., 2020). Its genome is arranged as 5'-R-S-E-M-N-A-3' (where R stands for replicas, $\mathrm{S}$ for the spike, $\mathrm{E}$ for the envelope, $\mathrm{M}$ for membrane, $\mathrm{N}$ for Nucleocapsid, and A for poly-adenine), as shown in Figure 1 (Chan et al., 2020). The SARS-CoV-2 virus is a member of the order "Nidovirals" and family "Coronaviridae" subfamily "Coronavirinae". This subfamily has further four genera (1) Alpha-coronavirus includes H-CoV-NL63 and H-CoV-229E (human corona viruses); (2) Beta-coronaviruses contains SARS$\mathrm{H}-\mathrm{CoV}$, HCV- 0C43, MERS-CoV, and HCoV-HKU1; (3) Gamma-coronaviruses contains birds and whales viruses; (4) Delta-coronaviruses contains viruses found in birds and pigs. SARS-CoV-2 is a peculiar beta-coronavirus that infects humans (Lu et al., 2020). 


\section{Coronavirus Structure and Protein Visualization}

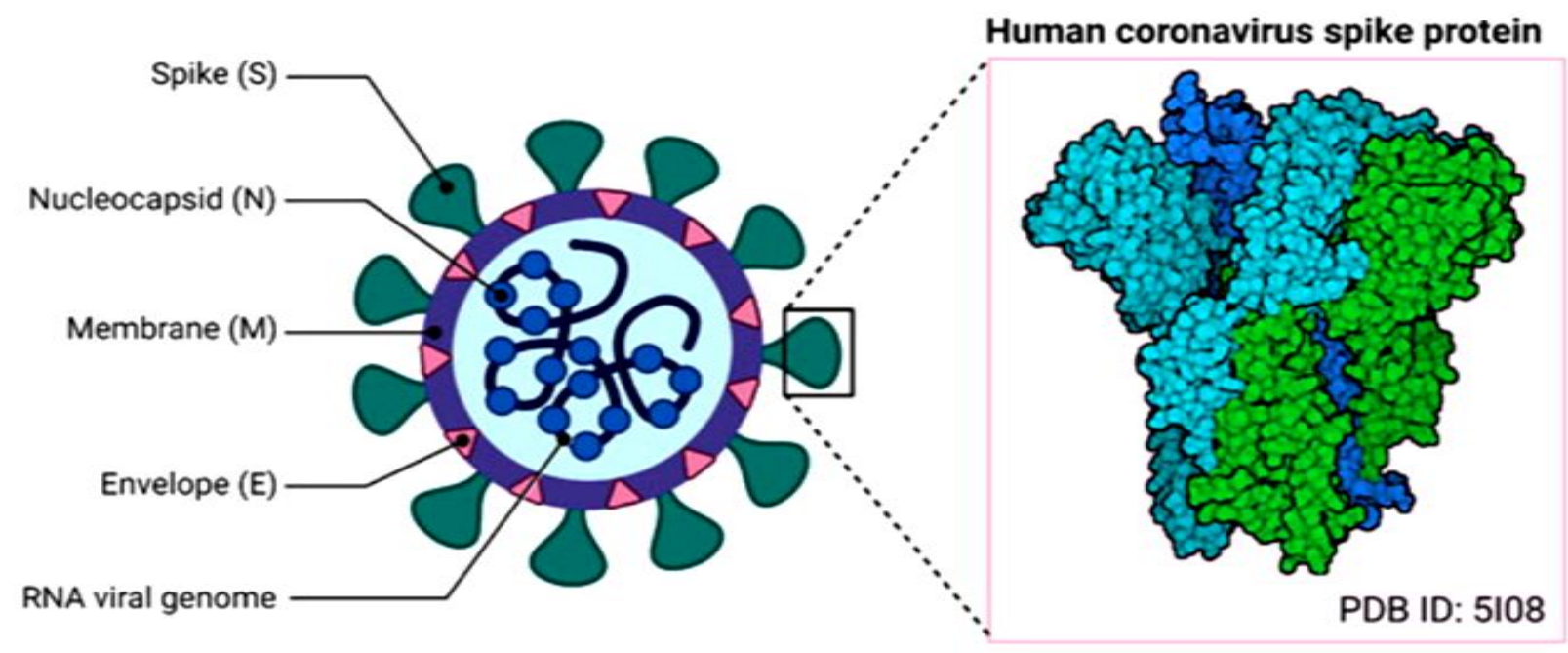

Figure 1 The 2019-nCoV structure and its protein visualization for active vaccine development. Coronaviruses belong in the family Coronaviridae and can cause disease in mammals and birds. The coronavirus spike (S) protein mediates membrane fusion by binding to cellular receptors (Bilal et al., 2020).

COVID-19 is a member of the family "Coronaviridae" and genera "Betacoronavirus"(Burrell et al., 2016). Coronaviruses are globally present in vertebrates, especially humans, and cause neurological, respiratory, hepatic, and enteric diseases. Most notable are the major epidemics of 2003 (SARS-CoV) and 2012 (MERS-CoV) infecting thousands of peoples. Comparative analysis indicates significant similarities and differences with the current outbreak; COVID-19 shows $79 \%$ genome similarities with SARS-CoV (de Wit et al., 2016). Both viruses require ACE2 (angiotensinconverting enzyme 2) receptors for gaining entry into the host's alveolar epithelial cell, induce cytokine storm in pulmonary endothelial cells, and predominantly attack and pass the infection to lower airways (Wan et al., 2020; Zhou et al., 2020). A mechanistic representation of endocytosis and exocytosis-based Corona virus entry and exit to and from the host, respectively, is shown in Figure 2.

\section{Transmission of COVID-19}

Corona viruses engage diverse subunit transcription/replication molecular machinery for its mechanism of action. Assembling of a group of non-structural proteins (that are cleavage products of viral proteins ORF-1ab and ORF-1a) aids in COVID-19 transcription and replication (Bilal et al., 2020; Buckman et al., 2020). Viruses require ACE2 (angiotensin-converting enzyme 2) receptors for gaining entry into the host's alveolar epithelial cell, induce cytokine storm in pulmonary endothelial cells, and predominantly attack and pass the infection to lower airways. RNA dependent RNA polymerase (a key nsp12, also known as RdRp) plays a vital role in the synthesis of RNA, thus playing a major role in viral transcription and replication with the help of other non-structural proteins like nsp7 and nsp8as cofactors (Subissi et al., 2014; Buckman et al., 2020).

Interestingly, molecular analysis has shown that the receptor for COVID-19 is an angiotensin-converting enzyme similar to SARSCoV (Hoffmann et al., 2020). These corona viruses use surface protein $\mathrm{S}$ to identify the required receptor on host cells; to gain entry into the target cells and results in infection. A genetic model study states that SARS-CoV-2 hasa ten-fold higher affinity to bind with ACE-2 than SARS-CoV, at a slightly higher level than the infection threshold (Wrapp et al., 2020). The detailed molecular study for binding of protein with receptor strength of their interaction and infection and how this novel virus causes organ damage are still unknown and more research in this area is needed. These detailed studies will explain the higher transmission capability of COVID-19, enhanced number of confirmed cases, the affinity of ACE2 for S protein, and potential treatment candidate (Wang et al., 2020).

Of all ages, regions, and cultures are susceptible. The novel viral infection spread through sneezing and coughing droplets by the symptomatic patient, even from asymptomatic and early-stage infection with the disease (Rothe et al., 2020). Research and diagnostic studies show a higher level of corona virus in the nasal cavity than in the throat with a similar viral burden in asymptomatic and symptomatic patients (Zou et al., 2020). Symptomatic patients are considered infectious even in clinical 


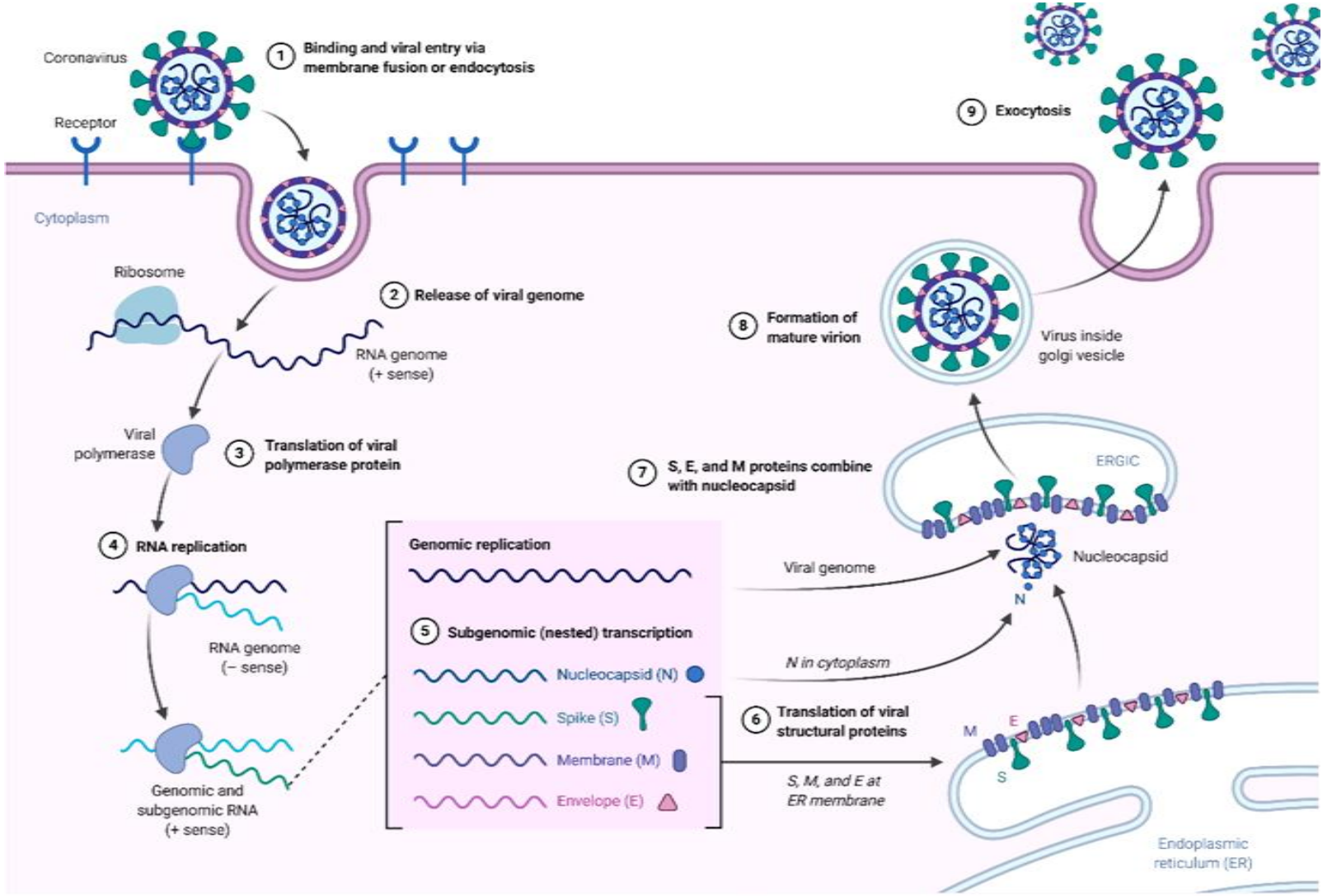

Figure 2 Representation of endocytosis and exocytosis-based Coronavirus entry and exit to and from the host, respectively(Iqbal et al., 2020).

recovery. The infected sneezing and coughing droplets can be deposited on the host surface even from a distance of 1-2 m. COVID-19 is viable for days if the environment is favorable; the viral infection is either spread through infected droplets inhalation or by touching infected surfaces and then nose or mouth. They are easily killed within seconds by general disinfectants like hydrogen peroxide, hypochlorite, etc. (Kampf et al., 2020). As RNA of infectious agent has been detected in stool, researchers are also suggesting its enteric route (feacal-oral route of infection) of infection (Chen et al., 2020; Ding \& Liang, 2020).

\section{Pathogenesis and immune response}

Beta-coronaviruses, like the majority of the corona-virus family, exhibit unique pathogenesis capability and specie specificity, fine genetic changes can significantly change their host range, tissue tropism, and pathogenicity. A prominent example of fit in changed circumstances human exposure to deadly zoonotic MERS-CoV (Zaki et al., 2012) and SARS-CoV diseases (Peiris et al., 2004). In both outbreaks, the natural reservoirs were bats, and terminal hosts were humans with intermediary hosts for MERS-CoV and SARSCoV were camels and palm civet, respectively (Guan et al., 2003; Alagaili et al., 2014). Intermediate hosts played the leading role of this cross-species transmission, as they enhance terminal host and virus contact and permit necessary adaption for efficacious replication in new humans (Brennan et al., 2014).

As novel SARS-COV-2 have pandemic prospects, careful watch and scrutiny are highly important to evaluate its viral evolution, pathogenicity, host adaption, and transmissibility. Molecular relationships (like receptor interaction) govern the viral host range. The receptor-binding domains (S-protein on the envelope) of SARS-CoV and SARS-CoV-2 were similar structurally despite the variation of amino acids at key places (Lu et al., 2020). Research studies predict that ACE2 is used by the novel virus to enter the host cells(Wan et al., 2020). Molecular analysis suggests that the COVID-19 spike protein has two domains $\mathrm{S} 1$ and S2, in which receptor binding is done by $\mathrm{S} 1$ and fusion of cell membrane by $\mathrm{S} 2$. $\mathrm{S} 1$ domain is more conserved in different corona viruses, whereas the S2 domain shows more variations (Lu et al., 2020).

In addition, recognition of Gln493 and Asn501 (key residues on COVID-19 receptor binding domain) that control binding with ACE2 of host cell supports that this novel virus has acquired the ability for transmission from person to person (Wan et al., 2020). Although spike proteins and pattern of COVID-19 is similar to 
SARS-CoV, at RNA level, it is jointly similar to SL-CoV-ZXC-21 and SL-CoV-ZC-45 (Harapan et al., 2020). However, specie specificity not only depends on binding efficacy with the receptor, encountering, and evading the host innate immune response is essential to drive pathogenesis. Research is being done to find the mechanism by which these novel viruses trickily dodge the defense system of the host (Chen et al., 2020). Due to unique features, corona infection is expanding at exponential rates. For example, if we took COVID-19 statistics of Pakistan for the last three months, we found that in starting, there were very few cases, but now thousands of patients get infected by this pandemic. In a viral infection, cellular and inflammatory responses are mediated by the host defense (immune) system to inhibit viral dissemination and replication(Felsenstein et al., 2020; Golonka et al., 2020). However, enhanced immune activation, together with the viral lytic effect on host cells, ultimately led to vicious pathogenesis. Clinical studies show that patients with viral infection suffer from fever, pneumonia, and dry cough as symptoms (Ali Shah et al., 2020; Chen et al., 2020). A considerable ratio of patients undergoes rapid septic shock or respiratory stress followed by organ failure, which led to the death of 1 in 10 serious patients.

Investigations suggest that critical patients in COVID-19 are presented with respiratory failure induced buy hyperinflammatory response and flood of cytokines. Poorly controlled and dysregulated cytokines release, which is synergized by the effect of immune responses, develop other clinical complications and give rise to a vicious cycle. This complicated and disorganized interaction of the immune system and several other regulatory substances consequently leads to multiple organ failures and ultimately leads towards death (Keam et al., 2020). Old age adult males are comparatively more prone to be infected with COVID19 and develop these complications more frequently (Malik et al., 2020).

\section{Clinical features and diagnosis of novel SARS-CoV-2}

Although COVID-19 has given diagnostic challenges in earlier stages of pandemic (Dinnes et al., 2020). Technological advances have made it possible to fight against and overcome the pandemic of COVID-19 of the $21^{\text {st }}$ century. This has made it possible to investigate the routes of transmission, survival, and factors affecting the prevalence and possible ways to reduce the spread of infection andit possible ways to reduce the complications associated with various phases of infectiuon (Afzal, 2020; Ai et al., 2020; Dhama et al., 2020; Dhama et al., 2020; Malik et al., 2020). This novel SARS-CoV-2 shows varied clinical features, commences with asymptomatic stage and ends with severe respiratory distress and organ damage. The clinical characteristics include dry cough, headache, fever, sore throat, breathlessness, conjunctivitis, and fatigue. Thus, they are similar to other respiratory infections. After seven days from onset of infection, a fraction of patients progressed to severe pneumonia, organ failure, and ultimately death. This continuance is linked with the upsurge of inflammatory cytokines, including IP10, TNF $\alpha$, IL-10, IL-2, MIP1A, IL-7, and GCSF (Guan et al., 2020; Wang et al., 2020). Severe complications due to COVID-19 include ARDS, major lung injury, acute kidney injury, and shock. The patients who persist this viral attack starts recovering in the second and third week, with the median treatment duration at the hospital was ten days. Adverse results are more frequent in the elderly with low immune response and those with fatal medical complications (Wang et al., 2020).

Specific COVID-19 diagnosis is made by specified molecular tests on samples (sputum, nasopharyngeal swab, throat swab, and endotracheal aspirates). Initially, national labs are offering these tests in case of emergency, but now a vast scale diagnosis is made even on a commercial level to screen the patients for infection from this novel virus. Other diagnostic investigations like blood chemistry, including RBC, WBC, Platelets, CRP, ESR counts, are non-specific and are not taken into consideration. WBC count is generally normal or low, platelet count may be low or normal, procalciton in level is routinely normal, but ESR and CRP levels are usually elevated. D-dimer, LDH, prothrombin time, ALT, AST, and CPK levels may be raised, and high up levels are indications for the severe disease (Singhal, 2020).

Computerized tomography (CT) scan investigations are more specific and sensitive for COVID-19. CT findings show abnormality in patients with no respiratory track clinical record/ asymptomatic individuals. In many cases, many suspected negative patients with abnormal CT values were found positive on repeat testing (Huang et al., 2020; Zhang et al., 2020). C-reactive protein, creatinine kinase, and lactate dehydrogenase elevation were demonstrated in most COVID-19 patients, but a small fraction of patients show high levels of serum creatinine and transaminase with an abnormal spectrum of the myocardial enzyme (Guan et al., 2020; Guan et al., 2020). Elevated IL-6 and IL-10 levels, and CD4+ $\mathrm{T}$ and CD8+ $\mathrm{T}$ low levels have been shown in COVID-19 patients (Wan et al., 2020).Another molecular research study shows elevated IFN, MCP1, IL1, and IP10. Highly serious patients admitted in ICU show increased levels of granulocyte colonystimulating factor (GCSF), TNF $\alpha, \mathrm{MCP} 1 \mathrm{~A}$, IP10, and MIP1A. Radiological test results differ with immunity status, disease progression, comorbidity, previous medication, and patient age (Jin et al., 2020).

SARS-CoV-2 produces severe viral respiratory infection with three days of incubation period in humans. The characteristic attributes of the novel corona virus in adults are noticeable. Most common are fever (88\%), cough (68\%), fatigue (38\%); vomiting (5\%) and diarrhea (4\%) are infrequent (Yang et al., 2020). In addition to this, serious cases are susceptible to diversified complications, 
including secondary infections, acute respiratory syndrome, and drastic heart injury. Scientific research verifies that this virus not only damages the lungs but also major organs and tissues of the body. In a research study on 214 COVID-19 patients, the neurological epitome was found in $35 \%$ of the patients (Mao et al., 2020; Mao et al., 2020). In addition, ocular infections were also evident in COVID-19 patients, and eye secretions were tested positive for viral RNA in these patients (Ai et al., 2020). Serious COVID-19 patients admitted to hospitals had an unusual liver function, abnormal renal function, arrhythmia, and serious heart injury ( $\mathrm{Li}$ et al., 2020). Tissue samples rectal mucosa, duodenum, and stomach of patients showed a positive result for COVID-19 RNA (Xiao et al., 2020).

As there is no prior exposure and proper treatment against COVID19, health institutes devised the Initial Response Plan (IRP) based on recommendations of WHO. The health commission of major countries devised the diagnosis and isolation plan for suspected cases. Steps were taken to setup diagnostic labs to confirm the presence of COVID-19 in suspected cases, and a person with the required symptoms, the positive test, and exposure history is categorized as a suspected case. RT-PCR is regarded asa major confirmatory test by WHO, while chest CT scan and other symptoms are secondary diagnosis factors. Negative patients are considered free of virus, and positive patients are classified as 'critical' with an extreme medical condition, 'Severe' with apparent symptoms and airways obstruction, 'mild' and 'moderate' with low viremia and fewer symptoms (Zu et al., 2020).

Different diagnostic techniques are employed to screen the individuals for COVID-19. Commonly used diagnostic procedures include PCR, ELISA, CT Scan, Lamp scan, and X-RAY (PCR being most specific). Hou et al. suggested diagnostic technology based on CRISPR because of certain limitations of these tests (Hou et al., 2020; $\mathrm{Hu}$ et al., 2020; Lu et al., 2020; Yu et al., 2020). Diagnostic screening properly ensures the isolation of infected and suspected cases from a negative (normal) population. Negative patients are either screened for different infection or sent back home, whereas infected cases are first isolated and then treated for viral infection and secondary complications, in term resistance to the spread of this disastrous viral infection

\section{RT-qPCR for SARS-CoV-2 detection}

In the current situation, a pandemic requires accurate diagnosis with a short turnaround time. Various testing strategies are used to diagnose infections. Molecular techniques suchas nucleic acid testing and detection are considered to be the gold standard, and positive nucleic acid confirms the presence of an infectious agent or pathogen (Carter et al., 2020; Cheng et al., 2020; Farfan et al., 2020; Lübke et al., 2020; Wu et al., 2020). In addition, certain diagnostic parameters can initially support the early detection of viral liberated particles such as point of care testing antigens, antibodies against an infectious agent, nucleic acid, etc. (Dinnes et al., 2020).

In the early stages of this pandemic, the SARS-CoV-2 complete genome was sequenced, and that genome clear the way for the synthesis of different primers and standardized assays for COVID19( $\mathrm{Lu}$ et al., 2020; Wu et al., 2020). The first Real-time PCR protocol targeting viral envelope (E), RNA dependent RNA polymerase (RDRP), genes (G), and Nucleocapsid (N) of COVID19 were documented on January 23, 2020 (Corman et al., 2020). The following generalized steps are followed for RT-PCR detection of SARS-CoV-2: extraction of RNA, probes, and primers targeting specified regions on viral genome, standard and controls making, and finally, real-time PCR assay.

PCR analysis is highly specific and regarded as the most accurate diagnostic analysis for COVID-19 but it has some limitations like false-positive and false-negative results. Molecular biologists worked on these and recommended somecritical steps to overcome this problem. False-negative results are caused by poor sample quality, handling, storage, extraction, transportation, and time of collection. Suggested measures to overcome this problem are to use extraction control, optimize the sample collection period, and RNasePin CDC assay (human housekeeping gene) quantitative detection. Factors that cause false-positive results are less-specific kits, which can be overcome by the use of highly specified assays and kits, sample contamination, which can be reduced by decontamination procedures and following proper SOPs. The final factor is cross-contamination, which can be diminished by the use of adequately designated areas for each step and use of appropriate negative and positive controls (NIH, Pak recommendations) (Carter et al., 2020; Farfan et al., 2020; Lübke et al., 2020).

\section{COVID-19 Real-time PCR testing facility in Pakistan}

At the end of February, the government of Pakistan and health institutes takes initiatives to set-up diagnostic labs to detect Corona virus in suspected patients. Initially, the turn-out was very low, COVID-19 kits were imported from different countries, but there is a shortage of required labs. The majority of diagnostic labs worldwide are employing PCR, ELISA, Lamp-based detection, and radiological based diagnosis for COVID-19. Each type of testing has its pros and cons. Radiological readings are manipulated by multiple factors like the immune condition of patients, recent medication, age of patients, and many other, ELISA based testing is sensitive but less specific. In contrast, PCR based diagnosis is the most particular technique to detect viral RNA in the patient but has less sensitivity and prone to false-negative results. A practical approach and advanced skills are required to reduce false-negative results and to enhance its sensitivity, which some research laboratories are employing by use of specific primers, reagents, and real-time analysis of viral RNA in the sample. 


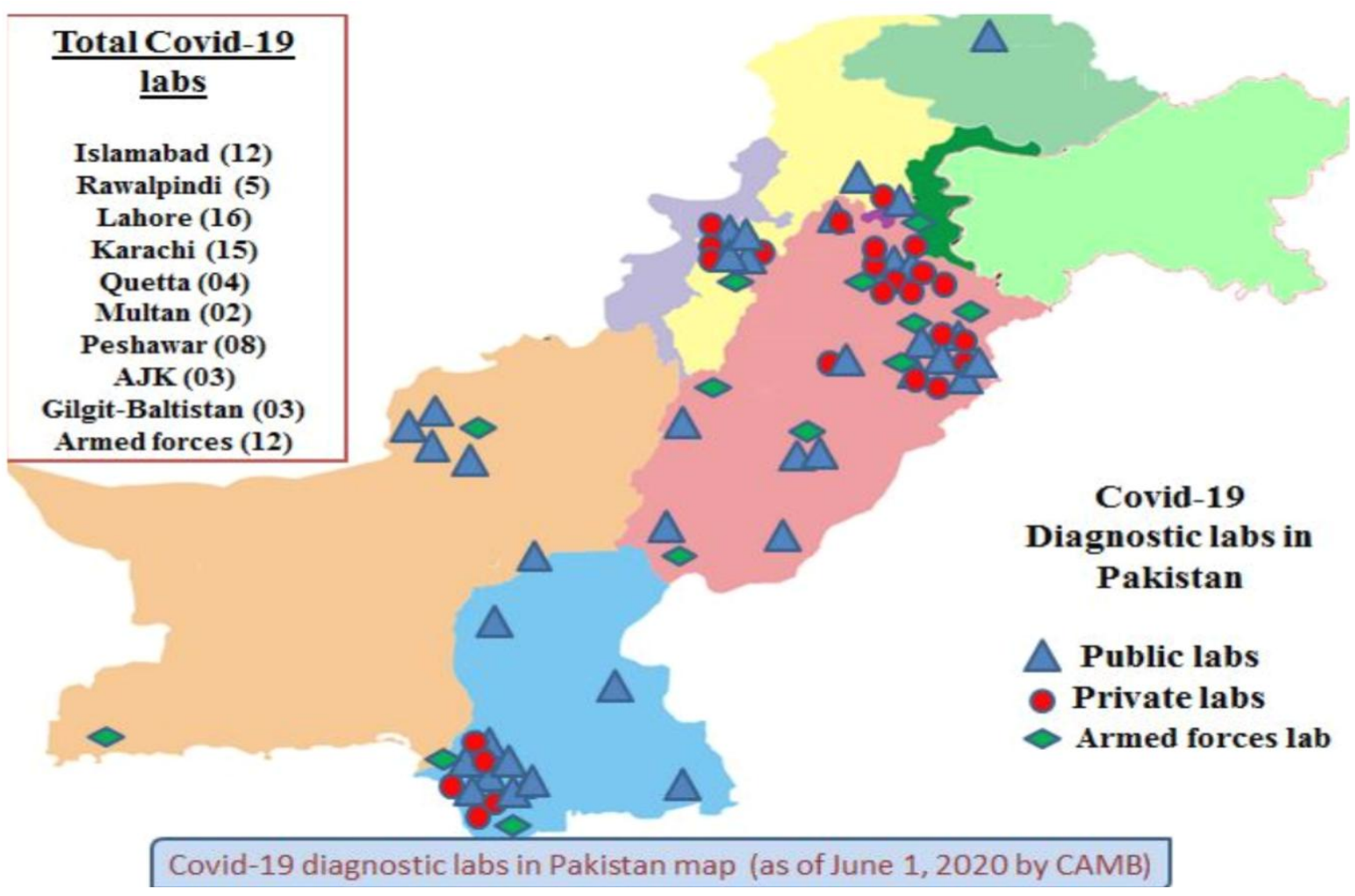

Figure 3 COVID-19 diagnostic labs in Pakistan map

According to recommendations by the National Institute of Health, Pakistan COVID-19 is expeditiously growing, and specified and timely diagnosis of this novel corona virus is ultimately require to control and properly manage this pandemic By looking at statistics, there is widespread demand for the creation of rapidly COVID-19 diagnostic testing labs in Pakistan. Scientists and healthcare workers work day and night and created 100 COVID-19 diagnostic labs in just 100 days with a total capacity greater than 30,000 tests per day. Area wise distribution of Public, private, and Armed forces diagnostic labs are shown in Figure 3.To support this initiative of the government of Pakistan, many research and molecular institutes come forward and dedicate their services to this emergency issue. Renowned CAMB Institute of Punjab University voluntarily has created the first institutional COVID-19 BSL-2 level laboratory. Punjab University (renowned and oldest institute of Pakistan) responded promptly to this call, and scientists worked hard day and night to play their role in curbing this disaster. Renowned Virologist Dr. Idrees Khan (Head of Virology division, Center for Excellence in Molecular Biology) created an indigenous COVID-19 detecting kit with cost 10X lower than the imported kits. Dr. Nazim (Head of Virology, therapeutic and diagnostic division, Center for Applied Molecular Biology, PU), with his tireless efforts, created the first-ever institutionalized Real-Time COVID-19 detection lab of Pakistan in no time. This lab is equipped with modern research facilities and is categorized in the BSL-3 level. This lab was inaugurated by Vice-Chancellor of Punjab University and Special Secretary Health on March 30, 2020. From that, this lab is regularly working and conducts more than 100 tests daily to aid the health department of the Punjab government. Due to this and many other initiatives, Pakistan is operating more than 17,000 COVID-19 diagnostic tests daily andhave a total capacity of 30,000 tests daily.

\section{Treatment and prevention of COVID-19}

By the start of this pandemic, no previous therapeutic approach was available. The vaccine has not been developed yet. The fast COVID-19 spread has stressed the demand for discovery and development of efficient vaccine and potential treatment (Sharun et al., 2020). Research is being done in different domains with unique approaches to treat the COVID-19 virus, nsp12 and RdRp are excellent targets to inhibit the virus, and clinical trials are being done with new therapeutics. At present, supportive treatment is provided for secondary complications to isolated and quarantined positive patients like antibiotic infusion, fluid management, and oxygen therapy for secondary medical conditions is recommended (Habibzadeh \& Stoneman, 2020; WHO, 2020). 


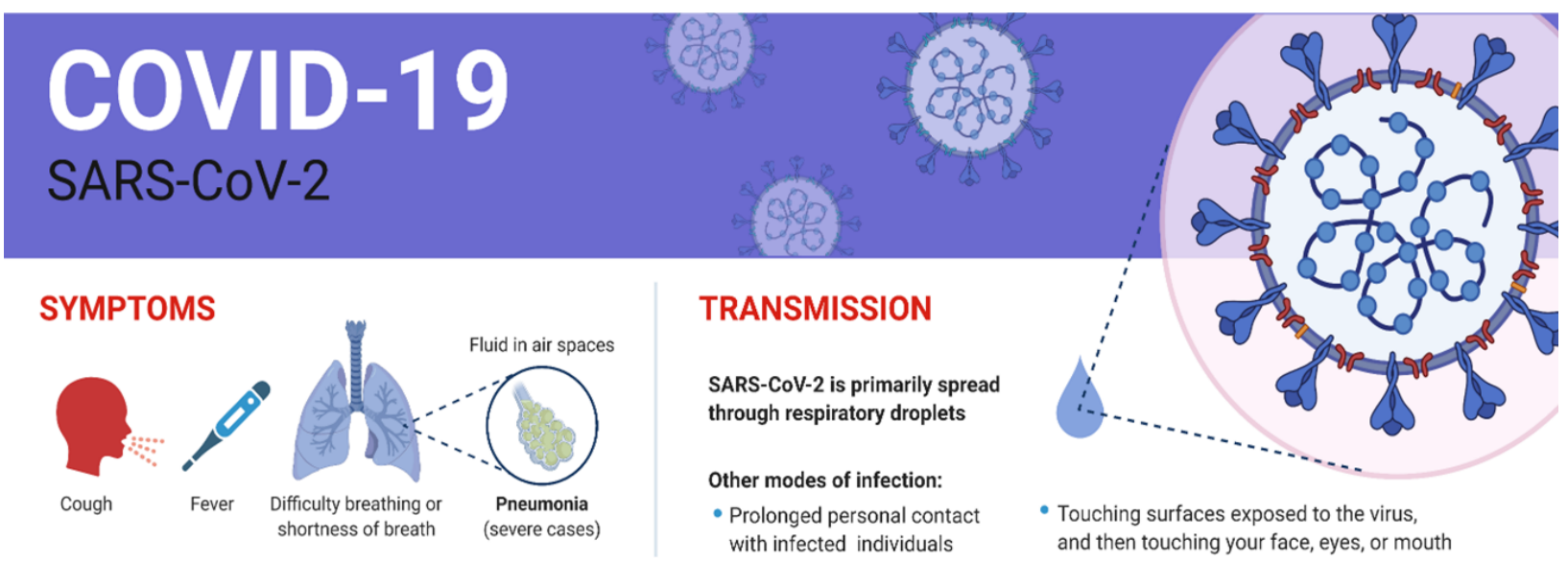

PREVENTION \& SAFETY
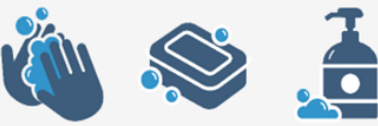

Wash and sanitize your hands frequently

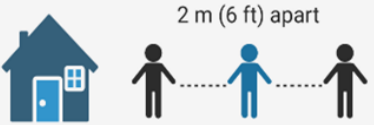

Self-isolate and practice social distancing

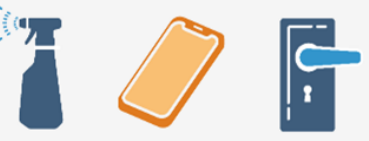

Disinfect high-touch surfaces

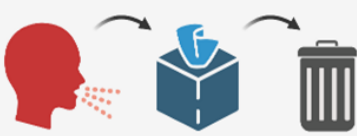

Cough into your elbow or tissues and dispose of tissues right away

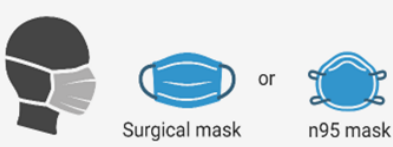

Wear a mask if you're sick or advised to

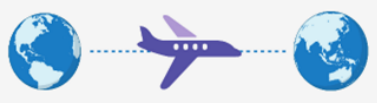

Avoid non-essential and international travel

\section{TREATMENT}

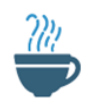

Stay hydrated

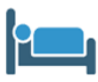

Get plenty
of rest

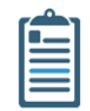

See your doctor (call ahead first)

\section{STAY INFORMED}

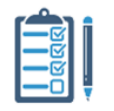

Monitor your symptoms

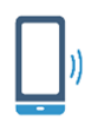

Refer to the WHO, CDC, and your local government for the most up-to-date and accurate information.

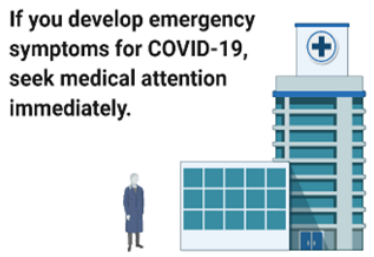

Information sources: CDC: https://www.cdc.gov/coronavirus/2019-ncov/if-you-are-sick/steps-when-sick.html ～～WHO: https://www.who.int/emergencies/diseases/novel-coronavirus-2019

Figure 4 Safety information and precautionary measures to put the current 2019-nCoV/COVID-19 outbreak in perspective (Shahbaz et al., 2020).

At present, there is no ultimate and approved treatment against COVID-19, so prevention is a practical approach to protect ourselves. Various therapeutic strategies have been being considered, and several drugs are being applied to reduce the severity of symptoms. Dexamethasone is considered to be useful in critically ill patients (Patel et al., 2020; Sharun et al., 2020). An old modality of therapy that almost had been forgotten, but this modality has shown a great promise during the pandemic of COVID-19 and has reduced the mortality significantly (Cunningham et al., 2020; Sharun et al., 2020). Several characteristics of the virus hinder the prevention procedure, namely, asymptomatic transmission, non-specific attributes of disease, infectivity before the symptomatic stage, high incubation time, prolonged illness, relapse, and post-recovery transmission (Jin et al., 2020). Of the effective approaches, recommended is the proper isolation of suspected, symptomatic, and confirmed cases. Individuals should follow personal protection, wear surgical masks, gloves, and frequent use of sanitizers, and follow cough hygiene (Figure 4). Homes should have enough access to sunlight to knockdown virion. Caregivers take proper protection and distance from suspected cases, wash their hands before entering and 
leaving their room, and should have the least contact with anything in that specified room. Confirmed and suspected patients should be isolated in separate vicinity having negative air pressure. Regular contamination should be done on equipment, rooms, and surfaces with disinfecting agents like hypochlorite. Practitioners should be protected with N95 respirators, shoe cover, and full gown; precautions should be taken while dealing with patients and are monitored and examined regularly for indications of COVID-19 (Chu et al., 2020; WHO, 2020).

The only way to prevent the spread of COVID-19 is to adopt social distancing strategies and preventive measures recommended by local and international experts.Until now, these strategies have proved to be the most worthy (Morawska \& Cao, 2020; Zhang et al., 2020). Experts suggest that good and balanced nutrition can helpfully maintain our immunity. It is considered to be essential to prevent and manage viral infections (Jaggers et al., 2020; Jayawardena et al., 2020). These steps to minimize the escalation of corona virus includes indoor and outdoor measures, dig out and isolate cases, identifying the latest contacts of the patient, travel check, social distancing initiatives and quarantine, and vaccines preparation, trials of medicines and treatments. As specific therapies and vaccines are present yet, other initiatives are playing an indispensable role in limiting the number of patients by many folds. These actions play their part by breaking the COVID-19 chain of transmission and intercepting the appearance of new cases.

\section{Conclusions and perspectives}

COVID-19 has challenged the medical, social, and financial infrastructure of the world in no time. At present, we can only predict the impact of the virus in the short and long run. Initially, the virus shows exponential growth in terms of the number of patients. Statistics of Pakistan and the world have shown that we are on the verge of disaster, as thousands of new cases are reported daily. Advanced diagnostic facilities across the globe that helped in identifying infected individuals and so breaking the chain of transmission, currently there are more than 100 COVID-19 diagnostic labs in Pakistan. Parallel to this, scientists are doing great to discover potential vaccine and treatment, and that will be available in a few months. This is just the first phase; such outbreaks of particular origin will continue to occur; efforts and research should be made in this regard to prepare and equip in advance to prevent a similar disaster from future outbreaks.

\section{Conflict of interest}

The listed author(s) declare no conflict of interest in any capacity, including competing or financial.

\section{Funding}

No funding was received for this study

\section{Authors' contribution}

All listed author(s) have made a substantial, direct, and intellectual contribution to the work and approved it for publication.

\section{References}

Abid K, Bari YA, Younas M, Tahir Javaid S, Imran A (2020) Progress of covid-19 epidemic in pakistan. Asia-Pacific Journal of Public Health 32(4): 154-156. DOI 10.1177/1010539520927259.

Afzal AJJOAR (2020) Molecular diagnostic technologies for covid-19: Limitations and challenges.

Ai JW, Zhang Y, Zhang HC, Xu T, Zhang WHJEM, Infections (2020) Era of molecular diagnosis for pathogen identification of unexplained pneumonia, lessons to be learned. Emerging Microbes and Infection 9(1): 597-600.

Ai T, Yang Z, Hou H, Zhan C, Chen C, Lv W, Tao Q, Sun Z, Xia L (2020) Correlation of chest ct and rt-pcr testing in coronavirus disease 2019 (covid-19) in china: A report of 1014 cases. Radiology 296(2):E32-E40. doi: 10.1148/radiol.2020200642..

Alagaili AN, Briese T, Mishra N, Kapoor V, Sameroff SC, de Wit E, Munster VJ, Hensley LE, Zalmout IS, Kapoor A (2014) Middle east respiratory syndrome coronavirus infection in dromedary camels in saudi arabia. MBio 5(2): e00884-00814.

Ali Shah ST, Mansoor M, Mirza AF, Dilshad M, Khan MI, Farwa R, Khan MA, Bilal M, Iqbal HMN (2020) Predicting covid-19 spread in pakistan using the sir model. J Pure Appl Microbiol, 14(2): $1423-1430 . \quad$ Available from https://microbiologyjournal.org/predicting-covid-19-spread-inpakistan-using-the-sir-model/ [Accessed 2020/07/02/16:26:09]. DOI 10.22207/JPAM.14.2.40.

Bilal M, Khan MI, Nazir MS, Ahmed I, Iqbal HJJOP, Microbiology A (2020) Coronaviruses and covid-19complications and lessons learned for the future. Journal of Pure and Applied Microbiology 1 (14): 725-731.

Brennan G, Kitzman JO, Rothenburg S, Shendure J, Geballe AP (2014) Adaptive gene amplification as an intermediate step in the expansion of virus host range. PLoS pathogens, 10(3).

Buckman SR, Glick R, Lansing KJ, Petrosky-Nadeau N, Seitelman LM (2020) Replicating and projecting the path of covid-19 with a model-implied reproduction number. Infectious Disease Modelling. DOI 10.1016/j.idm.2020.08.007.

Burrell CJ, Howard CR, Murphy FA (2016) Fenner and white's medical virology. Academic Press. 
Carter LJ, Garner LV, Smoot JW, Li Y, Zhou Q, Saveson CJ, Sasso JM, Gregg AC, Soares DJ, Beskid TR (2020) Assay techniques and test development for covid-19 diagnosis. ACS Publications.

Chan-Yeung M, Xu R (2003) Sars: Epidemiology. Respirology 8 suppl s9-14.

Chan JFW, Kok KH, Zhu Z, Chu H, To KKW, Yuan S, Yuen KY (2020) Genomic characterization of the 2019 novel humanpathogenic coronavirus isolated from a patient with atypical pneumonia after visiting wuhan. Emerging Microbes \& Infections 9(1): 221-236.

Chan JFW, Yuan S, Kok KH, To KKW, Chu H, Yang J, Xing F, Liu J, Yip CCY, Poon RWS (2020) A familial cluster of pneumonia associated with the 2019 novel coronavirus indicating person-to-person transmission: A study of a family cluster. The Lancet 395(10223): 514-523.

Chen L, Liu W, Zhang Q, Xu K, Ye G, Wu W, Sun Z, Liu F, Wu K, Zhong B (2020) Rna based mngs approach identifies a novel human coronavirus from two individual pneumonia cases in 2019 wuhan outbreak. Emerging Microbes \& Infections 9(1): 313-319.

Chen N, Zhou M, Dong X, Qu J, Gong F, Han Y, Qiu Y, Wang J, Liu Y, Wei Y (2020) Epidemiological and clinical characteristics of 99 cases of 2019 novel coronavirus pneumonia in wuhan, china: A descriptive study. The Lancet 395(10223): 507-513.

Chen Y, Chen L, Deng Q, Zhang G, Wu K, Ni L, Yang Y, Liu B, Wang W, Wei C, Yang J, Ye G, Cheng Z (2020) The presence of sars-cov-2 rna in the feces of covid-19 patients. Journal of Medical Virology 92(7): 833-840. DOI 10.1002/jmv.25825.

Cheng MP, Papenburg J, Desjardins M, Kanjilal S, Quach C, Libman M, Dittrich S, Yansouni CP (2020) Diagnostic testing for severe acute respiratory syndrome-related coronavirus 2: A narrative review. Annals of Internal Medicine 172(11): 726-734 Available from https://www.ncbi.nlm.nih.gov/pubmed/32282894. DOI 10.7326/M20-1301.

Chu DK, Akl EA, Duda S, Solo K, Yaacoub S, Schunemann HJ, on behalf of the COVID-19 Systematic Urgent Review Group Effort (SURGE) study authors (2020) Physical distancing, face masks, and eye protection to prevent person-to-person transmission of sars-cov-2 and covid-19: A systematic review and metaanalysis. Lancet 395(10242): 1973-1987. Available from https://www.ncbi.nlm.nih.gov/pubmed/32497510. 10.1016/S0140-6736(20)31142-9.

Ciotti M, Ciccozzi M, Terrinoni A, Jiang WC, Wang CB, Bernardini S (2020) The covid-19 pandemic. Critical Reviews in
Clinical Laboratory Sciences 57(6): 365-388. Available from https://www.ncbi.nlm.nih.gov/pubmed/32645276. DOI 10.1080/10408363.2020.1783198.

Corman VM, Landt O, Kaiser M, Molenkamp R, Meijer A, Chu DK, Bleicker T, Brünink S, Schneider J, Schmidt ML (2020) Detection of 2019 novel coronavirus (2019-ncov) by real-time rtpcr. Eurosurveillance 25(3): 2000045.

Cunningham AC, Goh HP, Koh D (2020) Treatment of covid-19: Old tricks for new challenges. Critical Care 24(1): 91. Available from https://www.ncbi.nlm.nih.gov/pubmed/32178711. DOI 10.1186/s13054-020-2818-6.

de Wit E, van Doremalen N, Falzarano D, Munster VJ (2016) Sars and mers: Recent insights into emerging coronaviruses. Nature Reviews Microbiology 14(8): 523.

Dhama K, Patel SK, Pathak M, Yatoo MI, Tiwari R, Malik YS, Singh R, Sah R, Rabaan AA,. Bonilla-Aldana DK, RodriguezMorales AJ (2020) An update on sars-cov-2/covid-19 with particular reference to its clinical pathology, pathogenesis, immunopathology and mitigation strategies. Travel Medicine and Infectious Disease doi: 10.1016/j.tmaid.2020.101755

Dhama K, Sharun K, Tiwari R, Sircar S, Bhat S, Malik YS, Singh KP, Chaicumpa W, Bonilla-Aldana DK, Rodriguez-Morales AJ (2020) Coronavirus disease 2019-COVID-19. Clinical Microbiology Reviews 33(4): e00028-00020.

Ding S, Liang TJ (2020) Is SARS-CoV-2 Also an Enteric Pathogen With Potential Fecal-Oral Transmission? A COVID-19 Virological and Clinical Review. Gastroenterology 159(1): 53-61. 10.1053/j.gastro.2020.04.052.

Dinnes J, Deeks JJ, Adriano A, Berhane S, Davenport C, Dittrich S, Emperador D, Takwoingi Y, Cunningham J, Beese S, Dretzke J, Ferrante Di Ruffano L, Harris IM, Price MJ, Taylor-Phillips S, Hooft L, Leeflang MM, Spijker R, Van Den Bruel A (2020) Rapid, point-of-care antigen and molecular-based tests for diagnosis of SARS-CoV-2 infection. Cochrane database of systematic reviews 8(Cd013705. DOI: 10.1002/14651858.Cd013705.

Dong E, Du H, Gardner L (2020) An interactive web-based dashboard to track COVID-19 in real time. The Lancet Infectious Diseases 20(5): 533-534. DOI: 10.1016/S1473-3099(20)30120-1.

Farfan MJ, Torres JP, Oryan M, Olivares M, Gallardo P, Salas C (2020) Optimizing RT-PCR detection of SARS-CoV-2 for developing countries using pool testing. Revista chilena de infectología 37(3): 276-280. DOI: $10.4067 /$ s071610182020000300276 . 
Felsenstein S, Herbert JA, Mcnamara PS, Hedrich CM (2020) COVID-19: Immunology and treatment options. Clinical Immunology 215(108448). DOI: 10.1016/j.clim.2020.108448.

Golonka RM, Saha P, Yeoh BS, Chattopadhyay S, Gewirtz AT, Joe B, Vijay-Kumar M (2020) Harnessing innate immunity to eliminate SARS-CoV-2 and ameliorate COVID-19 disease. Physiological Genomics 52(5): 217-221. DOI: 10.1152/physiolgenomics.00033.2020.

Guan WJ, Ni ZY, Hu Y, Liang WH, Ou CQ, He JX, Liu L, Shan H, Lei CI, Hui DS, Du B, Li LJ, Zeng G, Yuen KY, Chen RC, Tang CL, Wang T, Chen PY, Xiang J, Li SY, Wang JL, Liang ZJ, Peng YX, Wei L, Liu Y, Hu YH, Peng P, Wang JM, Liu JY, Chen Z, Li G, Zheng ZJ, Qiu SQ, Luo J, Ye CJ, Zhu SY, Zhong NS(2020) Clinical characteristics of 2019 novel coronavirus infection in China. The New England Journal of Medicine 382(18):1708-1720. DOI: 10.1056/NEJMoa2002032.

Guan Y, Zheng B, He Y, Liu X, Zhuang Z, Cheung C, Luo S, Li P, Zhang L, Guan Y (2003) Isolation and characterization of viruses related to the SARS coronavirus from animals in southern China. Science 302(5643): 276-278.

Habibzadeh P, Stoneman EK (2020) The novel coronavirus: a bird's eye view. The international Journal of Occupational and Environmental Medicine 11(2): 65.

Harapan H, Itoh N, Yufika A, Winardi W, Keam S, Te H, Megawati D, Hayati Z, Wagner AL, Mudatsir M (2020) Coronavirus disease 2019 (COVID-19): A literature review. Journal of Infection and Public Health 13(5):667-673. DOI 10.1016/j.jiph.2020.03.019.

Hoffmann M, Kleine-Weber H, Krüger N, Mueller MA, Drosten C, Pöhlmann S (2020) The novel coronavirus 2019 (2019-nCoV) uses the SARS-coronavirus receptor ACE2 and the cellular protease TMPRSS2 for entry into target cells. BioRxiv. DOI: 10.1101/2020.01.31.929042.

Holshue ML, Debolt C, Lindquist S, Lofy KH, Wiesman J, Bruce H, Spitters C, Ericson K, Wilkerson S, Tural A (2020) First case of 2019 novel coronavirus in the United States. New England Journal of Medicine 5:382(10):929-936. DOI: 10.1056/NEJMoa2001191.

Hou T, Zeng W, Yang M, Chen W, Ren L, Ai J, Wu J, Liao Y, Gou X, Li Y, Wang X, Su H, Gu B, Wang J, Xu T (2020) Development and evaluation of a rapid CRISPR-based diagnostic for COVID-19. PLOS Pathogens 16(8): e1008705. DOI: 10.1371/journal.ppat.1008705.

Hu X, Deng Q, Li J, Chen J, Wang Z, Zhang X, Fang Z, Li H, Zhao Y, Yu P, Li W, Wang X, Li S, Zhang L, Hou T (2020)
Development and Clinical Application of a Rapid and Sensitive Loop-Mediated Isothermal Amplification Test for SARS-CoV-2 Infection. mSphere 5(4): DOI: 10.1128/mSphere.00808-20.

Huang P, Liu T, Huang L, Liu H, Lei M, Xu W, Hu X, Chen J, Liu B (2020) Use of chest CT in combination with negative RT-PCR assay for the 2019 novel coronavirus but high clinical suspicion. Radiology 295(1): 22-23.

Iqbal HM, Romero-Castillo KD, Bilal M, Parra-Saldivar R (2020) The emergence of novel-coronavirus and its replication cycle: an overview. Journal of Pure and Applied Microbiology 14(1): 13-16.

Jaggers GK, Watkins BA, Rodriguez RL (2020) COVID-19: repositioning nutrition research for the next pandemic. Nutrition Research 81(1-6). DOI: 10.1016/j.nutres.2020.07.005.

Jayawardena R, Sooriyaarachchi P, Chourdakis M, Jeewandara C, Ranasinghe P (2020) Enhancing immunity in viral infections, with special emphasis on COVID-19: A review. Diabetology \& Metabolic Syndrome 14(4): 367-382. DOI: 10.1016/j.dsx.2020.04.015.

Jin YH, Cai L, Cheng ZS, Cheng H, Deng T, Fan Y-P, Fang C, Huang D, Huang LQ, Huang Q (2020) A rapid advice guideline for the diagnosis and treatment of 2019 novel coronavirus (2019$\mathrm{nCoV}$ ) infected pneumonia (standard version). Military Medical Research 7(1): 4

Kampf G, Todt D, Pfaender S, Steinmann E (2020) Persistence of coronaviruses on inanimate surfaces and its inactivation with biocidal agents. Journal of Hospital Infection104(3):246-251. DOI: 10.1016/j.jhin.2020.01.022.

Keam S, Megawati D, Patel SK, Tiwari R, Dhama K, Harapan H (2020) Immunopathology and immunotherapeutic strategies in severe acute respiratory syndrome coronavirus 2 infection. Reviews in Medical Virology DOI: 10.1002/rmv.212310.1002/rmv.2123.

Keni R, Alexander A, Nayak PG, Mudgal J, Nandakumar K (2020) COVID-19: Emergence, Spread, Possible Treatments, and Global Burden. Frontiers in Public Health 8: (216). DOI: 10.3389/fpubh.2020.00216.

Li Z, Wu M, Guo J, Yao J, Liao X, Song S, Han M, Li J, Duan G, Zhou Y (2020) Caution on kidney dysfunctions of 2019-nCoV patients. MedRxiv. DOI:10.1101/2020.02.08.20021212.

Lu R, Wu X, Wan Z, Li Y, Zuo L, Qin J, Jin X, Zhang C (2020) Development of a Novel Reverse Transcription Loop-Mediated Isothermal Amplification Method for Rapid Detection of SARS- 
CoV-2. Virologica Sinica 35(3): 344-347. DOI: 10.1007/s12250020-00218-1.

Lu R, Zhao X, Li J, Niu P, Yang B, Wu H, Wang W, Song H, Huang B, Zhu N (2020) Genomic characterisation and epidemiology of 2019 novel coronavirus: implications for virus origins and receptor binding. The Lancet 395(10224): 565-574.

Lübke N, Senff T, Scherger S, Hauka S, Andrée M, Adams O, Timm J, Walker AJJoCV (2020) Extraction-free SARS-CoV-2 detection by rapid RT-qPCR universal for all primary respiratory materials. Journal of Clinical Virology 5:130:104579. DOI: 10.1016/j.jcv.2020.104579.

Malik YS, Kumar N, Sircar S, Kaushik R, Bhat S, Dhama K, Gupta P, Goyal K, Singh MP, Ghoshal U, El Zowalaty ME, O RV, Yatoo MI, Tiwari R, Pathak M, Patel SK, Sah R, RodriguezMorales AJ, Ganesh B, Kumar P, Singh RK (2020) Coronavirus Disease Pandemic (COVID-19): Challenges and a Global Perspective. Pathogens. 9(7): DOI: 10.3390/pathogens9070519.

Malik YS, Kumar N, Sircar S, Kaushik R, Bhatt S, Dhama K, Gupta P, Goyal K, Singh MP, Ghoshal U (2020) Pandemic Coronavirus Disease (COVID-19): Challenges and A Global Perspective. Pathogens 2020 9(7):519. DOI: 10.3390/pathogens9070519.

Mao L, Jin H, Wang M, Hu Y, Chen S, He Q, Chang J, Hong C, Zhou Y, Wang D (2020) Neurologic manifestations of hospitalized patients with coronavirus disease 2019 in Wuhan, China. JAMA Neurology 77(6):683-690. DOI: 10.1001/jamaneurol.2020.1127.

Mao L, Wang M, Chen S, He Q, Chang J, Hong C, Zhou Y, Wang D, Miao X, Hu Y (2020) Neurological manifestations of hospitalized patients with COVID-19 in Wuhan, China: a retrospective case series study. MedRxiv DOI: 10.1101/2020.02.22.20026500.

Memish ZA, Perlman S, Van Kerkhove MD, Zumla A (2020) Middle East respiratory syndrome. The Lancet 28: 395(10229):1063-1077. DOI: 10.1016/S0140-6736(19)33221-0.

Morawska L, Cao J (2020) Airborne transmission of SARS-CoV2: The world should face the reality. Environment International 139(105730). DOI: 10.1016/j.envint.2020.105730.

World Health Organization (2020) Coronavirus disease 2019 (COVID-19): situation report, 73.

World Health Organization (2020) Coronavirus disease ( COVID19): weekly epidemiological, update. https://www.who.int/docs/default-source/coronaviruse/situationreports/20200831-weekly-epi-update-3.pdf?sfvrsn=d7032a2a_4.
World Health Organization (2020) Coronavirus disease (COVID19) technical guidance: Infection prevention and control. Availableat: https://www. who. int/emergencies/diseases/novelcoronavirus-2019/technical guidance/infection-prevention-andcontrol. Accessed. 28 March, 2020.

Patel SK, Saikumar G, Rana J, Dhama J, Yatoo MI, Tiwari R, Rodríguez-Morales AJ, Dhama KJTM, Disease I (2020) Dexamethasone: A boon for critically ill COVID-19 patients?. Travel Medicine and Infectious Disease 10:37:101844. doi: 10.1016/j.tmaid.2020.101844.

Peiris J, Guan Y, Yuen K (2004) Severe acute respiratory syndrome. Nature medicine 10(12): S88-S97.

Phan LT, Nguyen TV, Luong QC, Nguyen TV, Nguyen HT, Le HQ, Nguyen TT, Cao TM, Pham QD (2020) Importation and human-to-human transmission of a novel coronavirus in Vietnam. New England Journal of Medicine 382(9): 872-874.

Rothe C, Schunk M, Sothmann P, Bretzel G, Froeschl G, Wallrauch C, Zimmer T, Thiel V, Janke C, Guggemos W, Seilmaier M, Drosten C, Vollmar P, Zwirglmaier K, Zange S, Wölfel R, Hoelscher M (2020) Transmission of 2019-nCoV Infection from an Asymptomatic Contact in Germany. New England Journal of Medicine. 382(10): 970-971. 10.1056/NEJMc2001468

Shahbaz M, Bilal M, Moiz A, Zubair S, IqbalHM(2020) Food Safety and COVID-19: Precautionary Measures to Limit the Spread of Coronavirus at Food Service and Retail Sector. Journal of Pure and Applied Microbiology 14: 749-756.

Sharun K, Tiwari R, Iqbal Yatoo M, Patel SK, Natesan S, Dhama J, Malik YS, Harapan H, Singh RK, Dhama K (2020) Antibodybased immunotherapeutics and use of convalescent plasma to counter COVID-19: advances and prospects. Expert Opinion on Biological Therapy 20(9): 1033-1046. DOI: 10.1080/14712598.2020.1796963.

Sharun K, Tiwari R, Iqbal Yatoo M, Patel SK, Natesan S, Dhama J, Malik YS, Harapan H, Singh RK, Dhama K (2020) Antibodybased immunotherapeutics and use of convalescent plasma to counter COVID-19: advances and prospects. Expert Opinion on Biological Therapy 20: 1033 - 1046.

Singhal T (2020) A review of coronavirus disease-2019 (COVID19). The Indian Journal of Pediatrics 87: 281-286.

Subissi L, Posthuma CC, Collet A, Zevenhoven-Dobbe JC, Gorbalenya AE, Decroly E, Snijder EJ, Canard B, Imbert I (2014) One severe acute respiratory syndrome coronavirus protein complex integrates processive RNA polymerase and exonuclease 
activities. Proceedings of the National Academy of Sciences 111(37): E3900-E3909.

Wan S, Yi Q, Fan S, Lv J, Zhang X, Guo L, Lang C, Xiao Q, Xiao K, Yi Z (2020) Characteristics of lymphocyte subsets and cytokines in peripheral blood of 123 hospitalized patients with 2019 novel coronavirus pneumonia (NCP). MedRxiv. DOI: 10.1101/2020.02.10.20021832.

Wan Y, Shang J, Graham R, Baric RS, Li F (2020) Receptor recognition by the novel coronavirus from Wuhan: an analysis based on decade-long structural studies of SARS coronavirus. Journal of virology 94(7):e00127-20. DOI: 10.1128/JVI.00127-20.

Wang C, Horby PW, Hayden FG, Gao GF (2020) A novel coronavirus outbreak of global health concern. The Lancet 395(10223): 470-473.

Wang D, Hu B, Hu C, Zhu F, Liu X, Zhang J, Wang B, Xiang H, Cheng Z, Xiong Y (2020) Clinical characteristics of 138 hospitalized patients with 2019 novel coronavirus-infected pneumonia in Wuhan, China. Jama 323(11): 1061-1069.

Wang LS, Wang YR, Ye DW, Liu QQ (2020) A review of the 2019 Novel Coronavirus (COVID-19) based on current evidence. International Journal of Antimicrobial Agents 55 (6): 105948. https://doi.org/10.1016/j.ijantimicag.2020.105948.

Wrapp D, Wang N, Corbett KS, Goldsmith JA, Hsieh CL, Abiona O, Graham BS, Mclellan JS (2020) Cryo-EM structure of the 2019-nCoV spike in the prefusion conformation. Science 367(6483): 1260-1263.

Wu F, Zhao S, Yu B, Chen Y-M, Wang W, Song ZG, Hu Y, Tao ZW, Tian JH, Pei YY (2020) A new coronavirus associated with human respiratory disease in China. Nature 579(7798): 265-269.

Wu SY, Yau HS, Yu MY, Tsang HF, Chan LWC, Cho WCS, Yu CS, Yim A, Li M, Wong YKE, Pei XM, Wong CSC (2020) The Diagnostic Methods in the COVID-19 Pandemic, Today and in the Future. Expert Review of Molecular Diagnostics DOI: 10.1080/14737159.2020.181617110.1080/14737159.2020.1816171

Xiao F, Tang M, Zheng X, Liu Y, Li X, Shan H (2020) Evidence for gastrointestinal infection of SARS-CoV-2. Gastroenterology 158(6): 1831-1833. e1833.

Yang X, Yu Y, Xu J, Shu H, Liu H, Wu Y, Zhang L, Yu Z, Fang M, Yu T (2020) Clinical course and outcomes of critically ill patients with SARS-CoV-2 pneumonia in Wuhan, China: a single- centered, retrospective, observational study. The Lancet Respiratory Medicine 8(5):475-481. DOI: 10.1016/S22132600(20)30079-5.

Yang Y, Lu Q, Liu M, Wang Y, Zhang A, Jalali N, Dean N, Longini I, Halloran ME, Xu B (2020) Epidemiological and clinical features of the 2019 novel coronavirus outbreak in China. MedRxiv. DOI: 10.1101/2020.02.10.20021675.

Yu L, Wu S, Hao X, Dong X, Mao L, Pelechano V, Chen WH, Yin X (2020) Rapid Detection of COVID-19 Coronavirus Using a Reverse Transcriptional Loop-Mediated Isothermal Amplification (RT-LAMP) Diagnostic Platform. Clinical Chemistry 66(7): 975977. DOI: 10.1093/clinchem/hvaa102.

Zaki AM, Van Boheemen S, Bestebroer TM, Osterhaus AD, Fouchier RA (2012) Isolation of a novel coronavirus from a man with pneumonia in Saudi Arabia. New England Journal of Medicine 367(19): 1814-1820.

Zhang L, Du S, Gao S, Huang G, Li S, Chong W, Jia Z, Hou G (2020) CT features and artificial intelligence quantitative analysis of recovered COVID-19 patients with negative RT-PCR and clinical symptoms. Nuclear Medicine \& Medical Imaging DOI: 10.21203/rs.3.rs21021/v1.

Zhang R, Li Y, Zhang AL, Wang Y, Molina MJ (2020) Identifying airborne transmission as the dominant route for the spread of COVID-19. Proceedings of the National Academy of Sciences of the United States of America 117(26): 14857-14863. DOI: 10.1073/pnas.2009637117.

Zhou P, Yang X-L, Wang X-G, Hu B, Zhang L, Zhang W, Si H-R, Zhu Y, Li B, Huang CL, Chen HD, Chen J, Luo Y, Guo H, Jiang RD, Liu MQ, Chen Y, Shen XR, Wang X, Zheng XS, Zhao K, Chen QJ, Deng F, Liu LL, Yan B, Zhan FX, Wang YY, Xiao GF, Shi ZL (2020) A pneumonia outbreak associated with a new coronavirus of probable bat origin. Nature 579(7798): 270-273. DOI: $10.1038 / \mathrm{s} 41586-020-2012-7$.

Zou L, Ruan F, Huang M, Liang L, Huang H, Hong Z, Yu J, Kang M, Song Y, Xia J (2020) SARS-CoV-2 viral load in upper respiratory specimens of infected patients. New England Journal of Medicine. 382(12): 1177-1179.

Zu ZY, Jiang MD, Xu PP, Chen W, Ni QQ, Lu GM, Zhang LJ (2020) Coronavirus disease 2019 (COVID-19): a perspective from China. Radiology 200490. 